\title{
Perbedaan Somatometri Itik Tegal, Itik Magelang Dan Itik Pengging
}

\author{
Desi Wulandari $^{1 *}$, Sunarno $^{1 * *}$, Tyas Rini Saraswati ${ }^{1 * * *}$ \\ Laboratorium Biologi Struktur dan Fungsi Hewan, Jurusan Biologi FSM, Universitas Diponegoro, \\ J1. Prof. Soedarto, UNDIP, Tembalang, Semarang. 50275. \\ Email desiwulandaribio11@gmail.com
}

\begin{abstract}
Abstrct
Local ducks in Indonesia there are several kinds, for example Tegal ducks, Magelang ducks and Pengging duck each having characteristics different somatometri. Research on somatometri ducks that includes body weight, leg length, beak length, wing length, body length, and long-neck ducks important to know somatometri of each duck. This study aimed to analyze the differences somatometri at Tegal ducks, Magelang ducks and Pengging duck, which includes weight, leg length, beak length, wing length, body length, and a long neck. Ducks were used in this study maintained in the Central Breeding and Raising Ducks Work Unit Non Ruminant Livestock Banyubiru, Ambarawa. The study was conducted by measuring somatometri of each six monthold ducks. Duck samples taken from three different types of ducks that Tegal duck, Pengging duck and Magelang duck, of each type of sample taken many ducks as 6 tails. Data were analyzed using analysis of variance (ANOVA) with the differentiating factor is the type of duck. If the data were analyzed contained a real difference, then do a further test using the test Least Significant Differences (LSD) at 95\% confidence level. The results showed that there was no significant difference in all parameters of the study. Conclusion of the study three types of ducks will have somatometri not unlike that includes, weight, leg length, beak length, wing length, body length and the length of the neck. It was because give feed and feed same time.
\end{abstract}

Keywords: Local Ducks in Central Java, Somatometri, Tegal ducks, Magelang ducks, Pengging duck

Itik lokal di Indonesia ada beberapa macam, meliputi itik Tegal, itik Magelang dan itik Pengging yang masing- masing memiliki karakteristik somatometri yang berbeda-beda. Penelitian tentang somatometri itik yang mencakup bobot badan, panjang kaki, panjang paruh, panjang sayap, panjang tubuh, dan panjang leher itik penting dilakukan untuk mengetahui somatometri dari masing-masing itik. Penelitian ini bertujuan untuk menganalisis perbedaan somatometri pada itik Tegal, itik Magelang dan itik Pengging, yang meliputi bobot badan, panjang kaki, panjang paruh, panjang sayap, panjang tubuh, dan panjang leher. Itik yang digunakan dalam penelitian ini dipelihara di Balai Pembibitan dan Budidaya Ternak Non Ruminansia Satuan Kerja Itik Banyubiru, Ambarawa. Penelitian dilakukan dengan mengukur somatometri dari masing-masing itik yang berumur enam bulan. Sampel itik terdiri atas tiga itik lokal yang berbeda, yaitu itik Tegal, itik Magelag, itik Pengging. Jumlah masing-masing itik lokal adalah enam ekor. Data dianalisis menggunakan analisis variansi (ANOVA) dengan faktor pembeda adalah jenis itik. Apabila data yang dianalisis terdapat beda nyata, maka dilakukan uji lanjut menggunakan uji Least Significant Differences (LSD) pada taraf kepercayaan 95\%. Hasil penelitian menunjukkan bahwa tidak ada perbedaan nyata pada semua parameter penelitian. Kesimpulan penelitian ketiga jenis itik tersebut memiliki somatometri yang tidak berbeda yang meliputi, bobot badan, panjang kaki, panjang paruh, panjang sayap, panjang tubuh serta panjang leher. Hal ini disebabkan karena pakan yang diberikan serta waktu pemberian pakan yang sama.

Kata kunci : Itik lokal Jawa Tengah, Somatometri, itik Tegal, itik Magelang, itik Pengging

\section{PENDAHULUAN}

Itik merupakan jenis unggas air yang telah lama dikenal dan dimanfaatkan masyarakat sebagai salah satu sumber penghasil protein hewani, berupa telur dan daging (Suryana, 2011). Itik lokal di Indonesia ada 
beberapa macam, meliputi itik Tegal, itik Magelang dan itik Pengging. Penyebaran populasi itik sebagian besar terdapat di Pulau Jawa. Jenis bibit unggul yang diternakkan, khususnya di Provinsi Jawa Tengah adalah jenis itik petelur seperti itik Tegal, itik Magelang dan itik Pengging.

Ciri-ciri fisik itik Tegal, antara lain kepala kecil, leher langsing, panjang dan bulat, sayap menempel erat pada badan dan ujung bulunya menutup di atas ekor (Susanti dan Prasetyo, 2005). Itik Magelang memiliki bobot badan yang relatif lebih tinggi dibandingkan itik lokal lainnya (Ismoyowati dan Purwantini, 2009). Mulai berproduksi saat berumur 6 bulan dengan menghasilkan telur sekitar $130-170$ butir per tahun dan bobot baik jantan maupun betina, sekitar 1,4-1,75 kg (Haqiqi, 2008). Itik Pengging memiliki ciri-ciri badannya bulat bila berdiri tegak menyerupai botol, warna kaki dan paruh hitam dan tipis, mata lebar, kepala kecil dengan leher agak panjang, masa produksi 9-11 bulan per tahun dan warna kerabang telur biru muda kehijauan.

Produksi telur itik Pengging lebih unggul dibandingkan dengan itik Magelang dan itik Tegal (Suprijatna dkk., 2008). Produksi telur itik Tegal yang dicapai rata-rata sebesar 4.010 butir perbulan, dari jumlah ternak itik yang dipelihara bekisar antara 50 hingga 520 ekor, dengan rata-rata kepemilikan sebanyak 231 ekor, setiap ekor itik rata-rata hanya mampu menghasilkan telur sebanyak 208 butir per tahun (Bharoto, 2002). Itik Magelang memiliki produksi telur yang relatif lebih tinggi ditinjau dari Hen Day Production (HDP), yaitu sebesar 75,63 $\pm 20,68 \%$ dibanding itik Tegal dan itik Pengging, masing-masing 42,42 $\pm 17,72 \%$ dan $69,25 \pm 22,16 \%$ (Purwantini, 2002). Berdasarkan data BPS Kabupaten Semarang (2013), populasi itik petelur di Kabupaten ini mencapai $19,28 \%$ dari 367.493 ekor populasi itik dengan total produksi telur sebesar $19,27 \%$ dari 13.235.070 butir telur itik.

Krishan (2007), menyatakan bahwa keragaman fisik unggas dapat dijelaskan berdasarkan perbedaan ukuran dan bentuk tubuh, salah satunya dengan penentuan somatometri. Somatometri dapat digunakan untuk mengetahui ukuran dan bentuk tubuh ternak (Ogah et al., 2009). Pertumbuhan dan ukuran tubuh itik sangat dipengaruhi oleh pakan yang dikonsumsi, lingkungan sekitar, sistem perkandangan, dan potensi genetiknya (Setioko dkk., 2004). Pakan merupakan salah satu faktor penting dalam usaha peternakan, terpenuhinya kebutuhan pakan baik kualitas maupun kuantitas sangat menentukan penampilan produksi ternak, kelangsungan hidup ternak dan berbagai proses biologis dalam tubuh ternak (Sudiyono dan Purwatri, 2007). Pertumbuhan ternak tidak akan terganggu jika faktor lingkungan sekitar, pemeliharaan dan manajemen perkandangan terpenuhi dalam kondisi baik (Amaludin dkk., 2013). Produktivitas itik petelur juga dapat diketahui dari berbagai macam indikator yang terdapat pada tubuh yang mempunyai korelasi dengan kinerja sistem metabolisme. Belum banyak penelitian yang melaporkan penggunaan indikator ukuran somatometri untuk menentukan kinerja sistem metabolisme yang berkaitan dengan tingkat produktivitas itik petelur lokal, khususnya di Kabupaten Semarang.

Berdasarkan fakta tersebut, akan dilakukan penelitian tentang penentuan ukuran somatometri pada berbagai itik lokal yang terdapat di Kabupaten Semarang. Adapun, parameter somatometri yang akan diukur, meliputi bobot tubuh, panjang tubuh, panjang paruh, panjang sayap, panjang kaki, dan panjang leher. Ukuran somatometri dapat memberikan gambaran tentang efisiensi dan efektivitas proses metabolisme di dalam tubuh. Penelitian ini dilakukan untuk menganalisis perbedaan somatometri pada itik Tegal, itik Magelang dan itik Pengging, yang meliputi bobot badan, panjang kaki, panjang paruh, panjang sayap, panjang tubuh, dan panjang leher.

\section{BAHAN DAN METODE}

\section{Tempat dan Waktu Penelitian}

Penelitian ini dilaksanakan pada bulan September 2013. Pengambilan sampel itik Pengging, itik Tegal dan itik Magelang dilakukan di BPBTNR Ambarawa. Pengukuran parameter penelitian dilakukan di Laboratorium Biologi Struktur dan Fungsi Hewan Jurusan Biologi Fakultas Sains dan Matematika Universitas Diponegoro. 


\section{Bahan dan Alat}

Bahan penelitian meliputi sampel itik local, alkohol 70\%, tisu, dan kapas. Alat penelitian meliputi meliputi timbangan duduk, jangka sorong, penggaris, benang kasur dan kamera.

\section{Cara kerja}

\section{Pengambilan Sampel}

Itik yang digunakan adalah itik Tegal, itik Magelang dan itik Pengging yang di dapatkan dari BPBTNR Ambarawa. Sampel itik diambil secara acak dari tiap jenis itik dengan kriteria jenis kelamin yang sama, yaitu betina, umur yang relatif sama dan kondisi tubuh itik yang sehat.

\section{Rancangan Penelitian}

Penelitian ini menggunakan Rancangan Acak Lengkap (RAL) yang terdiri atas tiga perlakuan dengan $6 \mathrm{x}$ ulangan. Perlakuan terdiri atas tiga macam itik lokal yaitu, itik Magelag, itik Tegal dan itik Pengging.

\section{Prosedur Pengukuran Parameter}

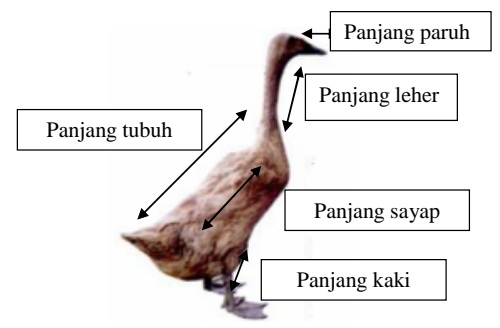

Gambar 1. Model Pengukuran Somatometri Itik

Parameter yang diamati adalah bobot badan, panjang kaki, panjang paruh, panjang sayap, panjang tubuh, dan panjang leher.

a. Bobot badan
Bobot badan itik Tegal, itik Magelang dan itik Pengging diperoleh dengan cara ditimbang menggunakan timbangan duduk.

b. Panjang tibia

Panjang tibia itik diukur dari tibia fibula hingga ke ujung femur dengan menggunakan benang kasur kemudian diukur dengan penggaris.

c. Panjang paruh

Panjang paruh itik diukur dari ujung paruh hingga kemulut dengan menggunakan benang kasur kemudian diukur dengan penggaris.

d. Panjang sayap

Panjang sayap itik diukur bagian ekstremitas anterior yang meliputi bagian humerus, radius, ulna dan karpal.

e. Panjang tubuh

Panjang tubuh itik diukur dari bagian tepat setelah esophagus hingga ke kelenjar uropigialis dengan benang kasur kemudian diukur dengan penggaris.

f. Panjang leher

Panjang leher itik diukur dari bagian setelah kepala yang meliputi esofagus dengan menggunakan benang kasur kemudian diukur dengan penggaris.

\section{Analisis Data}

Data yang diperoleh dianalisis menggunakan Analysis of Variance (ANOVA).

\section{HASIL DAN PEMBAHASAN}

Berikut ini adalah hasil penelitian, yang meliputi bobot itik, panjang tibia, panjang paruh, panjang sayap, panjang tubuh dan panjang leher dari masing-masing itik lokal Jawa Tengah, yaitu itik Tegal, itik Magelang dan itik Pengging disajikan pada Tabel 1 . 
Tabel1. Hasil analisis bobot itik, panjang tibia, panjang paruh, panjang sayap, panjang tubuh dan panjang leher dari ketiga jenis itik lokal yang di BPBTNR Ambarawa, Kabupaten Semarang.

\begin{tabular}{|lccc|}
\hline \multicolumn{3}{c}{ Parameter } & \multicolumn{3}{c|}{ Perlakuan } \\
\cline { 2 - 4 } & Itik Magelang & Itik Pengging & Itik Tegal \\
\hline $\begin{array}{l}\text { Konsumsi pakan } \\
\text { (g/ekor/hari) }\end{array}$ & $160,00^{\mathrm{a}} \pm 5,77$ & $170,00^{\mathrm{a}} \pm 5,77$ & $160,00^{\mathrm{a}} \pm 5,77$ \\
Panjang tibia (cm) & $19,333^{\mathrm{a}} \pm 0,875$ & $17,985^{\mathrm{a}} \pm 1,675$ & $17,583^{\mathrm{a}} \pm 0,917$ \\
Panjang paruh $(\mathrm{cm})$ & $7,833^{\mathrm{a}} \pm 0,408$ & $7,200^{\mathrm{a}} \pm 1,141$ & $7,583^{\mathrm{a}} \pm 0,583$ \\
Panjang sayap $(\mathrm{cm})$ & $34,750^{\mathrm{a}} \pm 2,484$ & $35,800^{\mathrm{a}} \pm 2,668$ & $35,166^{\mathrm{a}} \pm 1,032$ \\
Panjang tubuh $(\mathrm{cm})$ & $37,083^{\mathrm{a}} \pm 0,801$ & $38,683^{\mathrm{a}} \pm 0,877$ & $37,166^{\mathrm{a}} \pm 1,663$ \\
Panjang leher $(\mathrm{cm})$ & $18,666^{\mathrm{a}} \pm 1,402$ & $16,816^{\mathrm{a}} \pm 2,624$ & $18,250^{\mathrm{a}} \pm 2,067$ \\
& & & \\
Bobot itik $(\mathrm{g})$ & $149,01^{\mathrm{a}} \pm 126,872$ & $1530,0^{\mathrm{a}} \pm 213,91$ & $1480,0^{\mathrm{a}} \pm 115,1$ \\
\hline & & & \\
\hline
\end{tabular}

Keterangan: Angka dengan superskrip huruf yang sama pada lajur yang sama menunjukkan tidak berbeda nyata $(\mathrm{P}>0,05)$

Hasil analisis menunjukkan bahwa tidak terdapat perbedaan nyata pada itik Magelang, itik Pengging dan itik Tegal terhadap semua parameter, yang meliputi konsumsi pakan, panjang tibia, panjang paruh, panjang sayap, panjang tubuh, panjang leher dan bobot itik. Konsumsi pakan pada ketiga jenis itik yang tidak berbeda nyata disebabkan oleh berbagai macam faktor, antara lain faktor lingkungan, palatabilitas, dan jenis pakan. Faktor lingkungan berpengaruh pada tingkat konsumsi pakan itik, seperti temperatur. Semakin tinggi temperatur lingkungan akan menyebabkan konsumsi pakan itik semakin rendah. Temperatur yang tinggi dapat memicu pusat kontrol di hipotalamus untuk meregulasi pemeliharaan temperatur di dalam tubuh agar tetap konstan. Proses regulasi temperatur ini berdampak pada perubahan perilaku makan itik yang berakibat pada penurunan konsumsi pakan. Sebaliknya, temperatur lingkungan yang semakin rendah akan berpengaruh pada tingkat konsumsi pakan yang tinggi. Temperatur yang rendah akan memicu pusat control di hipotalamus untuk mengaktifkan mekanisme pemanasan, baik melalui kontruksi pembuluh darah di kulit maupun pengaktifan otot rangka. Kondisi ini membutuhkan ketersediaan energi yang cukup dari hasil proses metabolisme. Hal tersebut berpengaruh pada peningkatan konsumsi pakan itik untuk memenuhi kebutuhan energi yang dibutuhkan dalam proses pemeliharaan temperatur tubuh tersebut.

Faktor berikutnya yang berpengaruh pada tingkat konsumsi pakan adalah palatabilitas. Palatabilitas adalah sifat suatu bahan pakan yang dapat diketahui dari ciri-ciri organoleptiknya, meliputi tampilan, aroma, rasa dan tekstur (Rasyaf, 2004). Berdasarkan sifat palatabilitas pakan, ketiga jenis itik lokal memberikan respons terhadap tingkat konsumsi pakan yang tidak berbeda nyata (Tabel 4.1). Ketiga jenis itik lokal selama penelitian mendapatkan pakan dengan jumlah, komposisi, dan waktu pemberian yang sama. Pakan yang diberikan pada ketiga jenis itik lokal mengandung komposisi, antara lain karbohidrat $41,20 \%$, lemak $3,32 \%$, protein $19,86 \%$, bahan kering $85,62 \%$, air $11,40 \%$, abu $6,17 \%$, dan serat kasar $2,85 \%$.

Komposisi pakan merupakan faktor penting yang berpengaruh pada pertumbuhan itik. Pakan yang dikonsumsi oleh itik akan mengalami proses pencernaan di dalam saluran pencernaan. Karbohidrat yang merupakan salah satu nutrisi pakan (41,20\%) akan mengalami proses pencernaan, yang dimulai dari mulut, esofagus, ingluvies, proventrikulus, ventrikulus, dan usus halus yang melibatkan enzim-enzim spesifik. Proses pencernaan selanjutnya menghasilkan 
karbohidrat bentuk sederhana yang akan di absorbsi oleh sel-sel usus halus. Bahan baku metabolisme ini kemudian akan di transport menuju ke hati melalui vena porta hepatika, masuk ke dalam pembuluh darah, dan di transport ke sel target. Di dalam sel, karbohidrat sederhana seperti glukosa akan mengalami proses glikolisis dan senyawa yang dihasilkan akan masuk ke dalam siklus Krebs, oksidasi fosforilasi, dan rantai transport elektron untuk menghasilkan energi. Selanjutnya, energi yang dihasilkan digunakan untuk mendukung proses osifikasi, peningkatan sintesis lemak, pembentukan protein struktural, dan peningkatan massa otot rangka (Anggorodi, 1985; Murray dkk., 2009). Hal ini secara keseluruhan berpengaruh terhadap peningkatan ukuran panjang tibia, panjang paruh, panjang sayap, panjang tubuh, panjang leher dan bobot badan itik. Pengaruh pakan dengan komposisi karbohidrat yang sama yang diberikan dengan jumlah dan waktu pemberian yang sama menyebabkan berbagai macam parameter somatometri dan bobot badan dari ketiga jenis itik lokal tidak berbeda nyata.

Komposisi pakan untuk ketiga jenis itik lokal dalam penelitian ini juga mengandung lemak, sebanyak $3,32 \%$. Lemak pakan terdiri atas trigliserida, fosfolipid, kolesterol, dan ester kolesterol (Montgomery et al., 1993; Muchtadi dkk., 1993). Proses pencernaan lemak di dalam saluran pencernaan melibatkan lipase pankreas, garam empedu dan gerak peristaltik usus halus. Pencernaan lemak diawali dengan proses pembentukan emulsi lemak oleh agen pengemulsi yang terdiri atas garam empedu, lesitin, dan monogliserida yang bekerja di dalam usus halus. Proses emulsifikasi menyebabkan pemecahan butir-butir lemak menjadi unit-unit yang lebih kecil (Montgomery et al., 1993).

Garam empedu yang terdapat di dalam cairan empedu akan berinteraksi dengan lemak membentuk misel yang berfungsi melarutkan lemak dan menyediakan mekanisme transport lemak dari lumen ke dalam sel mukosa usus halus (Guyton dan Hall, 1997). Mekanisme tersebut akan menyebabkan lemak akan mengalami fragmentasi oleh proses agitasi usus halus menjadi unit-unit yang lebih kecil (Suparmi, 2005). Hasil emulsifikasi dan hidrolisis lemak yang melibatkan lipase pankreas menghasilkan monogliserida, asam lemak, dan gliserol dan sebagian kecil berupa digliserida dan trigliserida (Ganong, 1995). Asam lemak dan gliserol diabsorbsi kedalam membran mukosa usus halus dengan cara difusi pasif dan ditranspor kedalam sirkulasi darah melalui vena porta hepatika (Mathews et al., 1991). Gliserol dan asam lemak disintesis kembali menjadi trigliserida oleh retikulum endoplasma sel mukosa pada usus halus. Trigliserida dengan kolesterol dan fosfolipid selanjutnya akan berikatan dengan protein di dalam retikulum endoplasma membentuk lipoprotein yang disebut kilomikron. Selanjutnya, kilomikron akan menuju aparatus golgi untuk mendapatkan tambahan beberapa senyawa karbohidrat seperti manosa, galaktosa, glukosamin, dan asam sialat (Mathwes et al., 1991 ; Gilvery dan Goldstain, 1996). Kilomikron yang lebih kompleks akan dikeluarkan keruang antar sel pada jaringan epitel mukosa usus halus. Selanjutnya, kilomikron akan ditransport ke dalam sistem limfe, masuk ke sistem sirkulasi darah, dan menuju sel target. Di dalam sel, lemak akan dioksidasi oleh beta oksidase menghasilkan asam lemak dan gliserol. Selain itu, lemak juga mengalami proses oksidasi menghasikan asetil KoA. Senyawa ini kemudian akan diubah menjadi asam asetat melalui proses kondensasi, ditransport menuju jaringan perifer, dan dioksidasi untuk menghasilkan energi (Guyton dan Hall, 1997; Mathews et al., 1991). Secara keseluruhan, hasil metabolisme lemak digunakan untuk pemeliharaan integritas dan regenerasi sel, disimpan pada jaringan adiposa dan otot rangka, serta untuk mendukung proses-proses di dalam tubuh lainnya. Hal ini berpengaruh pada peningkatan ukuran panjang tibia, panjang paruh, panjang sayap, panjang tubuh, panjang leher dan bobot badan itik. Dengan demikian, pakan yang diberikan dengan kandungan lemak yang sama dan diberikan dengan jumlah dan waktu pemberian yang sama berdampak pada ukuran somatometri dan bobot badan yang tidak berbeda nyata antara ketiga jenis itik lokal.

Pencernaan yang dilanjutkan metabolisme protein mempunyai peran penting terhadap ukuran parameter somatometri dan bobot badan itik. Pencernaan protein $(19,86 \%)$ yang terkandung dalam pakan pada itik, dimulai di dalam lambung 
dengan melibatkan enzim pepsin hasil aktivasi pepsinogen oleh $\mathrm{HCl}$. Pepsinogen dihasilkan oleh sel Chief, sedangkan $\mathrm{HCl}$ dihasilkan oleh sel parietal lambung. Enzim pepsin berfungsi memecah protein menjadi polipeptida. Pencernaan protein berlanjut di usus halus, terutama di duodenum dengan melibatkan enzim enterokinase dan enzim-enzim yang disekresi oleh pankreas, meliputi tripsin, kimotripsin, dan karboksi peptidase. Beberapa enzim tersebut akan mengalami aktivasi dan berfungsi memecah polipeptida menjadi peptida. Beberapa enzim khusus, seperti aminopeptidase dan dipeptidase mempunyai peran penting dalam pemecahan dipeptida atau peptida menjadi asam amino. Asam-asam amino tersebut kemudian akan diabsorbsi ke dalam kapiler darah usus halus, masuk ke dalam sistem sirkulasi sistemik, menuju sel target dan mengalami proses metabolisme (Anggorodi, 1995). Dalam kondisi normal, hasil metabolisme protein hanya sebagian kecil yang digunakan untuk menjamin ketersediaan energi, sebagian besar hasil metabolisme protein digunakan untuk sintesis enzim, hormon, protein struktural, dan protein di dalam sel darah (Murtidjo, 1998). Dampak penggunaan hasil metabolisme protein ini adalah terjadinya perubahan pada parameter somatometri dan bobot badan itik lokal selama periode pertumbuhan sampai mencapai dewasa seksual. Namun demikian, somatometri dan bobot badan pada ketiga jenis itik lokal tidak berbeda nyata. Hal ini dapat disebabkan karena protein dalam pakan yang diberikan pada ketiga jenis itik lokal, baik kadar maupun jumlahnya sama.

Konsumsi pakan pada ketiga jenis itik lokal memiliki keterkaitan erat dengan parameter somatometri, yang meliputi panjang tibia, panjang paruh, panjang sayap, panjang leher, panjang tubuh, dan bobot badan itik. Bukti penelitian ini menunjukkan bahwa pemberian pakan dengan jumlah dan komposisi yang sama akan menghasilkan energi dan berbagai macam senyawa hasil metabolisme yang digunakan untuk mendukung proses pertumbuhan tulang, otot, dan jaringan lemak.

Pertumbuhan tulang diregulasi oleh hormon pertumbuhan (somatotropin) dan kalsium. Hormon pertumbuhan berperan dalam regulasi peningkatan jumlah dan ukuran sel-sel yang terlibat dalam proses osifikasi. Adapun, mineral kalsium mempunyai peran penting dalam proses deposisi dalam tulang untuk mendukung sel-sel yang terlibat secara langsung dalam proses osifikasi. Deposisi mineral kalsium ini melibatkan peran hormon kalsitonin yang disekresikan ke dalam darah oleh kelenjar tiroid. Sel-sel yang terlibat dalam proses osifikasi, seperti osteoblas dan osteoklas memiliki peran antagonis. Osteoblas berperan memicu pertumbuhan tulang (hiperplasia dan hipertropi), sedangkan ostepklas mengendalikan pertumbuhan tulang agar tercapai proses pembentukan tulang yang proporsional dan seimbang (Corwin, 2008; Rasjad, 2007). Osifikasi terjadi melalui dua tahap penting, yang diawali dengan osifikasi intramembran dan dilanjutkan dengan osifikasi endokondrium. Osifikasi intramembran adalah proses pembentukan jaringan tulang melalui penggantian jaringan serabut. Proses ini melalui beberapa tahap, antara lain perkembangan tulang spons di bagian pusat osifikasi, yang diikuti dengan pembentukan sumsum tulang merah di dalam jaringan tulang spons, yang berlanjut pada pembentukan tulang padat di bagian luar. Osifikasi berikutnya adalah osifikasi endokondrium. Proses ini bertujuan membentuk jaringan tulang dengan menggantikan rawan hilain. Osifikasi endokondrium diawali dengan pembentukan pusat osifikasi primer yang ditandai dengan terbentuknya rongga tulang hasil pemecahan rawan hialin dan dilanjutkan dengan pembentukan kuncup periosteum yang terdiri atas osteoblas, osteoklas, sumsum merah, saraf, pembuluh darah dan limfa. Beberapa komponen kuncup periosteum akan memasuki rongga sehingga terbentuk rongga di bagian medula. Bagian rongga ini semakin lama semakin membesar seiring penyebaran pusat osifikasi primer ke bagian ujung tulang. Proses berikutnya adalah pembentukan jaringan tulang padat yang menggantikan rawan di bagian luar tulang dan di dalam tulang panjang. Pembentukan pusat osifikasi primer dilanjutkan dengan pembentukan pusat osifikasi sekunder di bagian epifisis tulang. Selanjutnya, akan terjadi proses pembentukan rawan di bagian persendian yang terbentuk dari rawan yang tersisa di bagian luar epifisis. Lempeng epifisis dibentuk dari rawan yang tersisa 
di antara pusat perkembangan osifikasi primer dan sekunder yang membesar (Indriati, 2004).

Konsumsi pakan oleh ketiga jenis itik lokal juga berpengaruh terhadap pertumbuhan otot. Soeparno (2005) menyatakan, pertumbuhan otot pada masa pertumbuhan dan perkembangan itik di tandai dengan pertambahan matriks intraseluler dan ekstraseluler, pertambahan jumlah sel dan peningkatan ukuran sel. Junqueira dan Carneiro (2005) menyatakan, ketersediaan energi dalam sel otot rangka disimpan dalam bentuk glikogen, ATP, dan fosfokreatin. Glikogen merupakan hasil biosintesis glukosa. ATP dan fosfokreatin berasal dari pemecahan asam lemak dan glukosa. Asam lemak akan dipecah menjadi asam aseat oleh enzim beta oksidasi dalam siklus Krebs yang menghasilkan energi yang disimpan dalam bentuk ATP. Glukosa akan mengalami proses glikolisis menghasilkan asam piruvat. Senyawa ini selanjutnya akan mengalami proses dekarboksilasi oksidatif menghasilkan asetil KoA. Selanjutnya asetil KoA mengalami proses lebih lanjut menghasilkan asam oksalo asetat. Senyawa intermediet ini kemudian mengalami proses oksidasi fosforilasi dan rantai transport elektron yang menghasilkan energi. Kedua proses ini menghasilkan energi dalam jumlah besar yang disimpan dalam bentuk ATP. Ketersediaan ATP digunakan untuk mendukung proses yang berkaitan dengan pembentukan serabut otot dan jaringan ikat, pembentukan protein intraseluler dan ekstraseluler, peningkatan mioglobin dalam sarkoplasma, dan penambahan ukuran sel otot (hipertropi). Hal tersebut berdampak pada peningkatan massa sel otot dan sekaligus penambahan bobot badan pada ketiga jenis itik lokal.

Konsumsi pakan dari ketiga jenis itik lokal juga berpengaruh terhadap pertumbuhan jaringan lemak di dalam tubuh. Lemak yang terkandung dalam pakan digunakan sebagai sumber energi, sebagian digunakan untuk mendukung pemeliharaan integritas dan perbaikan seluler, serta disimpan pada jaringan lemak. Sel-sel tubuh dari ketiga jenis itik lokal dapat melakukan sintesis lemak dari asam lemak dan gliserol maupun hasil konversi karbohidrat terutama di dalam sel-sel hati dan jaringan lemak. Seiring dengan waktu, jaringan lemak akan berkembang secara proporsional pada beberapa bagian tubuh yang berbeda yang memberi kontribusi pada peningkatan massa tubuh itik. Secara umum, deposit lemak banyak ditemukan pada organ viseral (organ pencernaan), kulit (subkutan), diantara otot (intermuskuler), dan antara serabut otot atau intramuskuler (Bintang dkk., 1997).

Potensi genetis, anatomi, dan fisiologi pada ketiga jenis itik lokal memiliki keterkaitan erat dengan kapasitas daya dukung saluran pencernaan dan tingkat konsumsi pakan yang berpengaruh terhadap parameter somatometri dan bobot badan. Berdasarkan perbedaan potensi pada ketiga jenis itik lokal seharusnya memberikan pengaruh nyata pada perbedaan tingkat konsumsi pakan dan parameter somatometri ketiga itik tersebut. Namun, hasil penelitian ini memberi bukti bahwa perbedaan potensi pada ketiga jenis itik lokal tidak memberi pengaruh nyata terhadap tingkat konsumsi pakan, beberapa parameter somatometri dan bobot badan ketika pakan dengan komposisi nutrisi yang sama diberikan dengan jumlah dan waktu pemberian yang sama pada ketiga jenis itik tersebut. Selain itu, bukti ini menunjukkan bahwa potensi genetis, potensi metabolisme dan kapasitas daya dukung pencernaan tidak dapat berfungsi secara optimal jika pakan dengan kandungan nutrisi yang dimiliki diberikan dengan cara yang tidak proporsional sesuai dengan potensi yang dimiliki oleh ketiga jenis itik tersebut.

\section{KESIMPULAN}

Berdasarkan hasil penelitian dapat disimpulkan bahwa ketiga jenis itik tersebut memiliki somatometri yang tidak berbeda yang meliputi, bobot badan, panjang kaki, panjang paruh, panjang sayap, panjang tubuh serta panjang leher.Hal ini disebabkan karena jumlah dan komposisi pakan yang diberikan sama serta waktu pemberian pakan yang sama.

\section{UCAPAN TERIMA KASIH}

Penulis mengucapkan terima kasih kepada Ketua Laboratorium Biologi Struktur dan Fungsi Hewan dan Tim Peneliti Dosen yang telah membantu pelaksanaan penelitian sehingga hasil penelitian ini dapat dipublikasikan. 
DAFTAR PUSTAKA

Anggorodi, R. 1985. Manajemen Mutakhir Dalam Ilmu Makanan Ternak Unggas. PT. Gramedia, Jakarta.

Badan Pusat Statistik. 2013. Nilai Tukar Petani Kabupaten Semarang 2013. Katalog BPS: 7 102019.3322

Bharoto, T. 2002. Perencanaan dan Pengendalian Produksi. PT. Ghalia, Indonesia.

Bintang, I.A.K., Silalahi, Antawidjaja dan Raharjo. 1997. Pengaruh Berbagai Tingkat Kepadatan Gizi Ransum Terhadap Kinerja Pertumbuhan Itik Jantan Lokal dan Silangannya. Jurnal Ilmu Ternak dan Veteriner2 (4): 237-241. Balai Penelitian Ternak. Bogor. Diakses pada 24 Mei 2013.

Corwin, E.J. 2008. Buku Saku Patofisiologi (Edisi 3). EGC, Jakarta.

Ganong, W.F. 1995. Buku Ajar Fisiologi Kedokteran. Alih bahasa: petrus, Penerbit Kedokteran EGC, Jakarta.

Gilvery, R.W. dan Goldstain. 1996. Biokimia Suatu Pendekatan Fungsional. UNAIR Press, Surabaya.

Guyton, A.C. dan Hall. 2000. Buku Ajar Fisiologi Kedokteran. Ed ke-9. Terjemahan: Irawati Setiawan. EGC, Jakarta.

Hardjosworo, P.S., Setioko, Ketaren, Prasetyo, Sinurat dan Rukmiasih. 2001. Perkembangan Teknologi Unggas Air di Indonesia. Fapet IPB dan Balai Penelitian Ternak Pusat Penelitian dan Pengembangan Peternakan pp: $22-41$.

Haqiqi, H. 2008. Mengenal Beberapa Jenis Itik Petelur Lokal. Essay. Fakultas Peternakan Universitas Brawijaya, Malang.

Ismoyowati dan Purwantini. 2010. Isolasi dan Identifikasi DNA Itik Lokal untuk Memperoleh Keragaman Genetik sebagai Sumber Gen-Gen Unggul. Laporan Penelitian Fundamental Direktorat Jenderal Pendidikan Tinggi. Departemen Pendidikan Nasional. Fakultas Peternakan Universitas Jenderal Soedirman, Purwokerto.

Junqueira, L.U dan Carneiro. 2003. Histologi Dasar. CV EGC Penerbit Buku Kedokteran, Jakarta.
Krishan, K. 2007. Anthropometry In Forensic Medicine and Forensic Science Forensic Anthropometry. The Journal of ForensicScience, Vol. 2, No. 1, 2007.

Mathews, K.C., Van Holde and Kevin. 1991. Biochemistry. Third edition. Addisonwesley Publishing Company. USA

Montgomery, R.R.L., Dryer, Conway dan Spector. 1993. Biokimia Suatu pendekatan Berorientasi Kasus. Jilid 2. UGM Press. Yogyakarta.

Murtidjo. 1998. Beternak Bebek Lokal. Kanisius. Yogyakarta.

Purwantini. 2002. Produksi dan Kualitas Itik Lokal di Daerah Sentra Peternakan Itik. Unsoed, Purwokerto.

Rasyaf, M. 1997. Beternak Itik. Penerbit Kanisius, Yogyakarta.

Soeparno. 2005. Ilmu dan Teknologi Daging. Edisi 4. Gadjah Mada University Press, Yogyakarta.

Subhan, A., Yuwanta, Sidadolog dan Rohaeni. 2010. Pengaruh Kombinasi Sagu Kukus (Metroxylon Spp) dan Tepung Keong Mas (Pomacea Spp) Sebagai Pengganti Jagung Kuning Terhadap Penampilan Itik Jantan Alabio, Mojosari dan MA. JITV15(3): 165 173.

Sudiyono dan Purwatri. 2007. Pengaruh Penambahan Enzim Dalam Ransum Terhadap Persentase Karkas dan BagianBagian Karkas Itik Lokal Jantan. Jurnal Pengembangan Peternakan Tropis. 32: 270277.

Suprijatna, E., Atmomarsono dan Kartasudjana. 2008. Ilmu Dasar Ternak Unggas. Penebar Swadaya. Jakarta.

Suryana. 2011. Karakterisasi Fenotipik dan Genetik Itik Alabio Dan Pemanfaatannya di Kalimantan Selatan Secara Berkelanjutan. Disertasi. Sekolah Pascasarjana Institut Pertanian Bogor, Bogor.

Susanti, T. dan Prasetyo. 2005. Panduan Karakterisasi Ternak Itik. Pusat Penelitian dan Pengembangan Peternakan. Bogor. 
